\title{
Sex pheromones and reproductive isolation in two nereid species, Nereis succinea and Platynereis dumerilii
}

\author{
E. Zeeck, J. Hardege, H. Bartels-Hardege \\ Institute for Chemistry and Biology of the Marine Environment (ICBM), University of Oldenburg, D-2900 Oldenburg, \\ Germany
}

\begin{abstract}
About 50 volatile compounds of the coelomic fluid of ripe Nereis succinea were concentrated with a closed loop stripping technique and identified by coupled gas chromatography and mass spectroscopy. Gas chromatographic analysis showed the similarity of the volatile compounds of coelomic fluid of $N$. succinea and Platynereis dumeriliz. The sex pheromone of $P$, dumerilii, 5-methyl-3heptanone, was likewise found in $N$. succinea where it is also biologically active - it induces an increase of activity in the nuptial dance behaviour and the release of a small cloud of sperm in males. In $N$. succinea the threshold concentration is about 25 times higher than in $P$. dumerilii. In these 2 nereid species, living and reproducing in the same area, 5-methyl-3-heptanone plays an important role in species recognition and reproductive isolation.
\end{abstract}

\section{INTRODUCTION}

The reproductive form of Nereis succinea is the metamorphosed heteronereis, which is highly specialized for reproduction and has a distinctive reproductive behaviour, swarming and nuptial dance. Epitokous specimens release sex pheromones during swarming to stimulate partners of the opposite sex. Boilly-Marer \& Lassalle (1978) showed that in Platynereis dumerilii the nuptial dance behaviour and gamete release is synchronized by pheromones present in the coelomic fluid of ripe individuals. Boilly-Marer \& L'Homme (1986) extracted a fraction from males of $P$. dumerilii which contained several steroids and induced gamete release in females. They showed that the active substance is probably gorgosterol, with some modifications of the chemical structure of the side chain (BoillyMarer \& L'Homme 1986). This steroid substance is still not fully chemically characterized. The nuptial dancecoordinating pheromone 5-methyl-3-heptanone was identified recently by Zeeck et al. (1988). There exist 2 sex-specific enantiomers, the $\mathrm{S}(+)$ produced by the males and acting on females and the $\mathrm{R}(-)$ from the females acting on males.

Boilly-Marer \& Lassalle (1980) showed heterospecific activity of the coelomic fluid from males of various nereid species, i.e. coelomic fluid of Platynereis dumerilii is biologically active in Nereis succinea. In their experiments they used an electrophysiological bioassay, which is a sensitive test for pheromones in insects (Arn et al. 1975) and in the highly specialized nereids (Boilly-Marer 1974, Boilly-Marer \& Lassalle 1978,1980 ). In the brackish Isefjord (Denmark), $N$. succinea is abundant along with other Nereis species such as $N$. diversicolor, $N$. pelagica, $N$. virens and $P$. dumerilii. While $N$, diversicolor, $N$. virens and $N$. pelagica reproduce in spring, $N$. succinea and $P$. dumerilii reproduce during summer. Ripe $N$. succinea assemble at the water surface in swarms during the dark phase of the moon in June and July for reproduction (Rasmussen 1973, Hardege et al. 1990), a period when $P$. dumerilii also reproduces there.

In the present investigation volatile compounds of the coelomic fluid of Nereis succinea were concentrated with a closed loop stripping method, analyzed and identified by gas chromatography (GC) and coupled gas chromatography-mass spectroscopy (GC-MS) and checked for biological activity in $N$. succinea.

\section{MATERIAL AND METHODS}

Atokous Nereis succinea were collected in the Weser Estuary, Germany, in 1988 and maintained in 
glass tubes as described by Goerke (1979). Seawater was obtained from the Biologische Anstalt Helgoland, Germany, filtered through charcoal, pasteurized by heating to $80^{\circ} \mathrm{C}$ for $30 \mathrm{~min}$, and diluted with distilled water to $17 \%$. Commercially available fish food and living specimens of Corophium volutator were used as food. Artificial illumination (50 lx) was used with a daylength of $16 \mathrm{~h}$. According to the method of Franke (1985), moonlight was simulated by glim lamps (0.25 lx), synchronised with the natural lunar phase (light for 4 consecutive nights every $30 \mathrm{~d}$ ). This laboratory stock produced mature specimens around the time of new moon. For induction of metamorphosis atokous specimens were maintained under temperature regimes as described by Hardege et al. (1990), which allowed us to obtain ripe specimens throughout the year. (The reproduction phase in the field is June to August.) As soon as metamorphosis was completed, it was possible to divide sexes for further maintenance. For pheromone identification epitokous, swarming specimens were additionally caught in the Isefjord in June 1988 and 1989.

To extract volatile compounds, coelomic fluid of about 100 Nereis succinea (both sexes) was diluted with fresh pasteurized seawater to a total volume of $2 \mathrm{I}$. Using a closed loop stripping technique (Grob \& Zürcher 1976), volatile compounds were transferred into the gas phase and trapped on a charcoal filter. To prevent biological degradation during extraction process the sample was conserved with sodium azide $\left(1.95 \mathrm{~g} \mathrm{l}^{-1}\right)$ and acetyl iodide $\left(185.5 \mathrm{mg} \mathrm{l}^{-1}\right)$. After desorption with acetone the volatile compounds were analyzed and identified by GC and MS (Finnigan Ion
Trap Detector: ITD 800). The electrophysiological bioassay was carried out according to Boilly-Marer \& Lassalle (1978), who described the effects of sex pheromones on the central nervous system of Platynereis dumerilii (details in Zeeck et al. 1988). Behavioural assays were carried out with synthetic racemic 5-methyl-3-heptanone, $\mathrm{S}(+)$ and $\mathrm{R}(-)$ enantiomers and extracts according to Zeeck et al. (1988) to examine chemosensory effects, the influence on individual specimens and the induction of gamete release.

\section{RESULTS}

\section{Identification}

Gas chromatographic analysis of coelomic fluid of Nereis succinea showed more than 80 volatile substances (Fig. 1). A number of compounds were verified by comparing MS data and GC retention times with synthetic material. The identification was sometimes based solely on MS data. In such cases these data left no doubt as to the structure of the substances, or their mass spectra were in agreement with the mass spectra of other homologues also present in the coelomic fluid thus providing evidence supporting the proposed structure. As described for Platynereis dumerilii (Zeeck et al. 1988), some of these substances (Table 1), like the benzenes, aldehydes and $n$-alkanes, are also present in seawater, but in much lower concentrations (Fig, 1). About 20 compounds, mainly ketones and alkenes, were present only in the coelomic fluid of the heteronereids (Table 2). One of the major compounds is

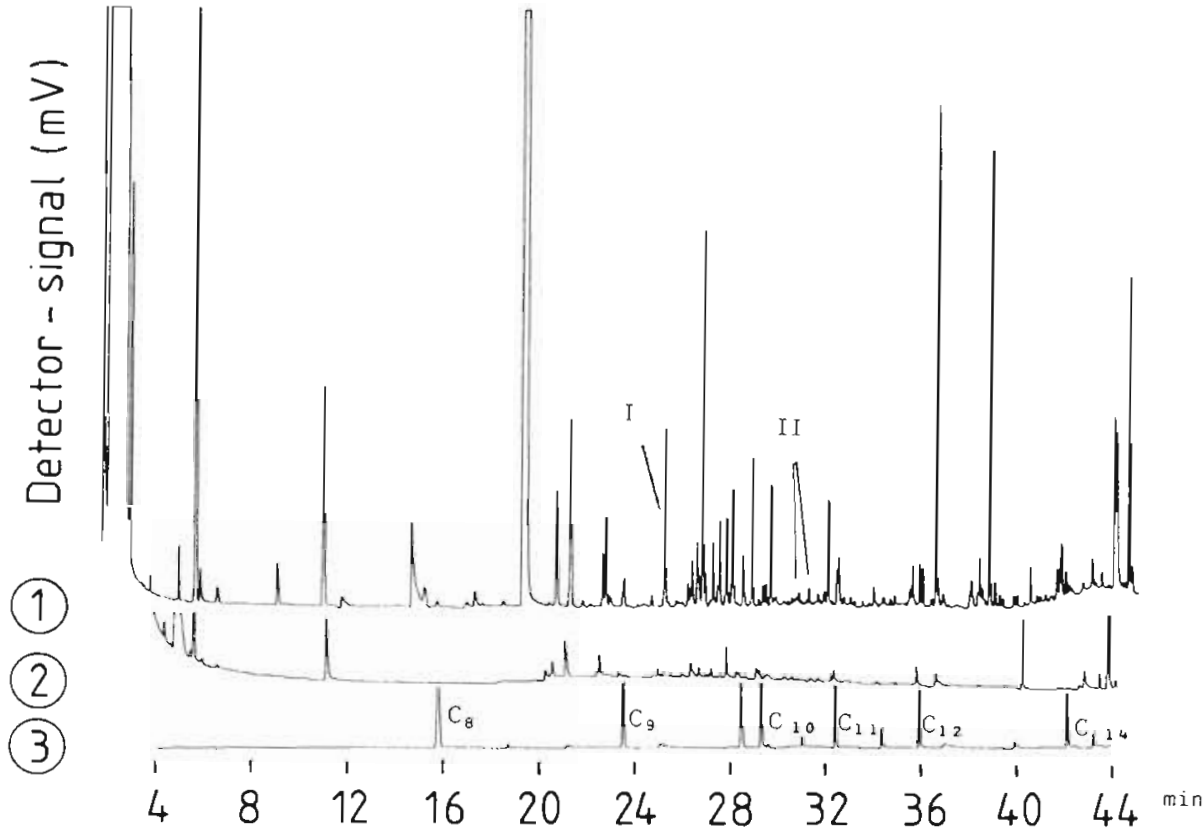

Fig. 1. Nereis succinea. Gas chromatogram. Extracts from 1: $N$. succinea, 2: seawater (4 times lower attenuation), and $3: C_{7}$ to $\mathrm{C}_{15}$. I: 5-methyl-3-heptanone; II: 3,5-octadien-2-one (E, E; E, Z). Conditions: fused silica capillary column DB5 $30 \mathrm{~m} \times 0.25 \mathrm{~mm}$; carrier gas $\mathrm{H}_{2}\left(2 \mathrm{ml} \mathrm{min}^{-1}\right)_{\text {; tempera- }}$ ture progression: $15 \mathrm{~min}$ at $30^{\circ} \mathrm{C}$; $5^{\circ} \mathrm{C} \mathrm{min}^{-1}$, final temp. $190^{\circ} \mathrm{C}$ 
Table 1. Nereis succinea. Volatile compounds of coelomic fluid, also detectable in smaller amounts in seawater

\begin{tabular}{|llll|}
\hline Benzenes & $n$-Alkanes & Aldehydes & Others \\
\hline Toluene & Nonane & Hexanal & Bicyclo(2.2.1)hept-2-ene-1,7,7-trimethyl \\
$m$-Xylene & Decane & Heptanal & 1-cyclohexene-1-carboxyaldehyde-2,6,6- \\
Ethylbenzene & Undecane & Octanal & trimethyl \\
1,3,5-trimethyl-benzene & Dodecane & Nonanal & \\
o-Ethyltoluene & Tridecane & Decanal & \\
$m$-ethylbenezene & Pentadecane & & \\
$1,2,3$-trimethyl-benzene & & & \\
1,3 -dimethyl-2-ethyl-benzene & & & \\
$1,2,3,5$-tetramethyl-benzene & & & \\
$p$-Isopropyltoluene & & \\
$1,2,4,5$-tetramethyl-benzene & & \\
1,2 -dimethyl-4-ethyl-benzene & & \\
\end{tabular}

Table 2. Nereis succinea. Volatile compounds of coelomic fluid identified from ripe males and females

\begin{tabular}{lll|}
\hline Ketones & Alkenes & Others \\
\hline 2-hexanone & 1,3,5-octariene & 2-nonene-1-ol \\
2,4-dimethyl-3-hexanone & bicyclo(4-2.0)-octa-1,3,5-triene & Dimethyldisulfane \\
5-methyl-3-heptanone & E,E 3,5-octadien-2-one & Dimethyltrisulfane \\
6-methyl-3-heptanone & E,Z 3,5-octadien-2-one & 2-ethyl-furane \\
6-methyl-2-heptanone & 5-nonene-2-one & 2-pentyl-furane \\
3-octanone & 2,4-decadienal & 5-methyldecane \\
2-nonanone & 2,4-undecadienal & \\
2-decanone & & \\
2-undecanone & & \\
\hline
\end{tabular}

the sex pheromone of $P$. dumerilii, 5-methyl-3-heptanone, which is present in an amount of about $10 \mathrm{ng}$ in each specimen in the sample. The second sex pheromone of $P$. dumerilii, 3,5-octadien-2-one, which is a female-specific substance (Zeeck et al. unpubl.), is also found as 2 isomers ( $E, E ; E, Z$ ).

\section{Bioassays}

As described for Platynereis dumerilii (Zeeck et al. 1988), in Nereis succinea no chemosensory effect was observable when the ketone 5-methyl-3-heptanone was added to swarming specimens in a 4 -tube test chamber (Zeeck et al. 1988). Swarming heteronereids were not attracted by the ketone or coelomic fluid of the opposite sex. Addition of racemic ketone to single swarming specimens (in a $100 \mathrm{ml}$ dish with fresh pasteurized seawater) induced an abrupt increase of swimming activity of both males and females (Table 3) and sometimes induced swimming in narrow circles. During this swarming behaviour the specimens often touched the water surface (about 10 times $\min ^{-1}$ ). Approximately $2 \mathrm{~min}$ after the addition of the ketone, the specimens were removed carefully from the test dishes and transferred to a separate dish, which had been used immediately beforehand to check the effect of 5-methyl-3-heptanone on the other sex. In nearly all experiments $(95 \%, \mathrm{n}=90)$ gamete release took place. In addition, after removing males and placing females

Table 3. Nereis succinea. Behavioural bioassays with ripe, swarming specimens: reaction to synthetic sex pheromone 5-methyl-3-heptanone

\begin{tabular}{|c|c|c|c|c|}
\hline & \multicolumn{2}{|c|}{ Nuptial dance } & \multicolumn{2}{|c|}{ Gamete release } \\
\hline & $\delta^{5}$ & $q$ & 0 & q \\
\hline Coelomic fluid $(\delta)$ & - & + & - & + \\
\hline Coelomic fluid $(q)$ & + & + & + & $(+)^{a}$ \\
\hline $20 \mathrm{ng} \mathrm{l}^{-1} \mathrm{~S}(+)$ & - & + & - & - \\
\hline $20 \mathrm{ng} \mathrm{l}^{-1} \mathrm{R}(-)$ & + & - & $t^{c}$ & - \\
\hline $0.5 \mathrm{ng} \mathrm{l}^{-1}$ racemic & - & - & - & - \\
\hline $5.0 \mathrm{ng} \mathrm{l}^{-1}$ racemic & - & - & - & - \\
\hline $20 \mathrm{ng} \mathrm{l}^{-1}$ racemic & + & + & $+^{c}$ & - \\
\hline $50 \mathrm{ng} \mathrm{l}^{-1}$ racemic & + & + & $+^{c}$ & - \\
\hline $100 \mathrm{ng} \mathrm{l}^{-1}$ racemic & + & + & $+^{c}$ & - \\
\hline $500 \mathrm{ng} \mathrm{l}^{-1}$ racemic & $(+)^{b}$ & $(+)^{b}$ & - & - \\
\hline $1 \mu \mathrm{g} \mathrm{l}^{-1}$ racemic & - & - & - & - \\
\hline \multicolumn{5}{|c|}{${ }^{a}$ About $50 \%$ of specimens ( $n=23$, reacting: 12 ) } \\
\hline \multicolumn{5}{|c|}{ A About $28 \%$ of speciemens ( $n=21$, reacting: 6 ) } \\
\hline${ }^{c}$ Small cloud of spe & & & & \\
\hline
\end{tabular}




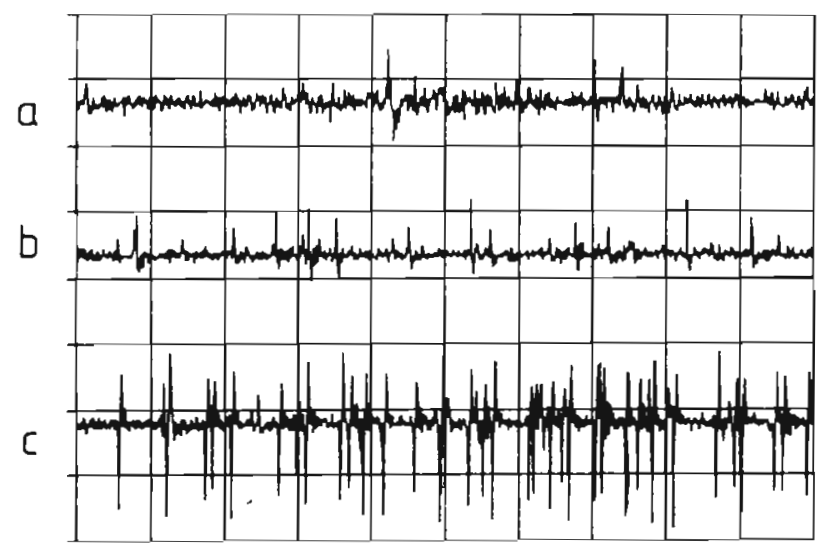

Fig. 2. Nereis succinea. Electrophysiological assay: influence of 5-methyl-3-heptanone and 3,5-octadien-2-one on the electrical activity of the brain of mature $N$. succinea. (a) Control response to seawater; (b) immediate response; (c) 1 min after adding 5-methyl-3-heptanone. Ordinate: $10 \mu \mathrm{V}$ division ${ }^{-1}$; abscissa: $500 \mathrm{~ms}^{\text {division }}{ }^{-1}$

in a dish, part of the eggs (10 to $20 \%$ ), released immediately by the females, were fertilized (Table 3 ). In a control without 5-methyl-3-heptanone no fertilized eggs were found.

In the electrophysiological (Fig. 2) and behavioural bioassays the threshold concentrations of racemic 5 methyl-3-heptanone were not identical. Although specimens detected the pheromone in electrophysiological assays at a concentration of $0.5 \mathrm{ng} \mathrm{l}^{-1}$, a behavioural effect was found at a threshold of $17.5 \mathrm{ng}$ $1^{-1}\left(\mathrm{n}=47 ; \mathrm{SD} 2.5 \mathrm{ng} \mathrm{l}^{-1}\right)$. Addition of higher doses of the pheromone (up to $20 \times$ threshold) induced the same behaviour, whereas concentrations over $50 \times$ threshold reduced the percentage of reacting specimens (Fig. 3). There exist 2 sex-specific enantiomers, the $R(-)$ produced by females and acting on males and the $\mathrm{S}(+)$ produced by males with biological activity only on females (Table 3 ). This is similar to Platynereis

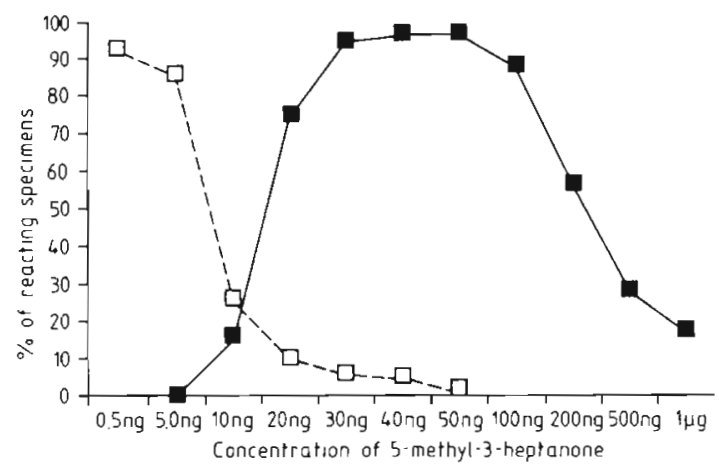

Fig. 3. Nereis succinea and Platynereis dumerili. Species recognition by species-specific concentrations of the sex pheromone 5-methyl-3-heptanone (synthetic, racemic). (- $\rightarrow$ N succinea; $(\square---)$ P. dumerilii dumerilii (Zeeck et al. 1988). Both isomers of 3,5-octadien-2-one $(E, E ; E, Z)$ had biological activity in the electrophysiological bioassay (Fig. 2), but no behavioural effect in Nereis succinea.

\section{Species recognition}

In electrophysiological as well as in behavioural bioassays ( $\mathrm{n}=22$ for Platynereis dumerilii, $\mathrm{n}=18$ for Nereis succinea), coelomic fluid of both species acted heterospecifically and in both sexes. That is, both sexes released gametes in the presence of coelomic fluid or entire specimens of the opposite sex of the other species. Comparing present results for $N$. succinea with results for $P$. dumerilii taken from Zeeck et al. (1988), Fig. 3 shows the relation between 5-methyl-3-heptanone concentration and behavioural responses of males of these 2 species. At the concentration for maximum response of $N$. succinea to 5-methyl-3-heptanone only $10 \%$ of the swarming $P$, dumerilii will react. On the other hand, $N$. succinea is not able to detect and react to a concentration readily detected by $P$. dumerilii (Fig. 3).

\section{DISCUSSION}

The coelomic fluid of Nereis succinea contains very nearly the same volatile compounds as described for the related species Platynereis dumerilji (Zeeck et al. 1988). Most of these compounds may originate from eggs or coelomic fluid of females as described also for $P$. dumerilii by Zeeck et al. (unpubl.). Both sex pheromones identified in $P$. dumerilii, 5-methyl-3-heptanone and 3,5-octadien-2-one, were also present in $N$. succinea and the sex-specific enantiomers of 5-methyl3-heptanone induce the same behaviour as in $P$. dumerilii. There is an increase of swarming activity during the nuptial dance behaviour in both sexes, and the males additionally release a small cloud of sperm, which in the next step of the reproduction behaviour induces egg release by the female. The females release another pheromone which induces males to release masses of sperm. This substance is still unknown, but fractionation of the volatile compounds after GC separation (Fig. 1) shows a still unidentified compound with biological activity in electrophysiological bioassays. Further investigations to identify this compound are under way. The second unknown compound found in both $N$. succinea and $P$. dumerilii is the gamete release pheromone which induces the females to spawn. Boilly-Marer \& L'Homme (1986) suggested that this could be a steroid, probably chemically related to gorgosterol, but were not able to identify this substance.

As shown here (Table 3) for Nereis succinea and by 
Zeeck et al. (1988) for Platynereis dumerilii, the responses to 5-methyl-3-heptanone feature loss of activity at higher concentrations. This phenomenon is also found in some insects. The larch bud moth Zeiraphera diniana is attracted by low concentrations of the pheromone trans-11-tetradecenyl acetate, but high concentrations had no effect (Roelofs et al. 1971).

The heterospecifity of the coelomic fluid of nereids in inducing gamete release is described by Boilly-Marer \& Lassalle (1980), who suggested that family-specific sex pheromones occur in the Nereidae. Contrary to this, Boilly-Marer (1969) found that females of Platynereis dumerilii spawn when exposed to the coelomic fluid of male Glycera convoluta. In the Isefjord Nereis succinea reproduces naturally around new moon during night-time at the water surface (Hardege et al. 1990 ), where $P$. dumerilii also reproduces around the first quarter of the moon.

However, there is an overlap of the swarming activity by the 2 species during the week after the new moon (Hardege et al. 1990). At that time species recognition and reproductive isolation is provided by the sex pheromone 5-methyl-3-heptanone which prevents direct contact of the 2 species. In the reproductive behaviour of both species, slowly swimming females and fast swimming males pass each other after the first contact and subsequently move towards each other in decreasing circles until finally they swim in narrow circles around their sexual partner. The male releases a small cloud of sperm followed by egg release by the female. Finally the male releases large clouds of its sperm (Zeeck et al. 1988). The use of 5-methyl-3heptanone in the different species-specific concentrations can lead to a behaviour in which for example a $N$. succinea male does not detect a female of $P$. dumerilii when they pass and $P$. dumerilii males will not react to the higher doses of the pheromone emitted by a slowly swimming female of $N$. succinea.

Although the use of different main attractants is the most obvious way of achieving reproductive isolation in insects, closely related species may employ the same pheromone systems mainly in alarm behaviour, but also for attraction of a sexual partner. In some species the rate of pheromone release from the specimens is the species-specific cue. Klun \& Robinson (1972) reported an example of male discrimination among release rates in leafroller species. Cis-11-tetradecenyl acetate was most attractive to male oblique banded leafrollers Choristoneura rosaceana at high pheromone release rates, whereas the European corn borer Ostrinia nubialis was most attracted to low concentrations. High release rates were not attractive at all. In the 2 closely related noctiuds Trichloplusia ni and Autographa california, the cabbage looper and the alfalfa looper, Kaae et al. (1973) showed the importance of the pheromone concentration as a reproductive isolating mechanism. These noctiud species overlap in geographical distribution, seasonal cycles and mating rhythms as Nereis succinea and Platynereis dumerilii do. In a heterogeneous population of these looper species, Kaae et al. (1973) showed that $T$. ni males were attracted by release rates of the pheromone cis-7dodecenyl acetate at concentrations 10 to 100 times those attracting $A$. california. For the latter species high release rates were unattractive in laboratory experiments and field trapping tests. The findings in noctiuds indicate a reproductive isolation mechanism similar to that described here for the marine polychaetes $N$. succinea and $P$. dumerilii - the use of different concentrations of the same pheromone by closely related species.

Acknowledgements. Field observations were carried out at the Isefjord Laboratory (Denmark). We are grateful to Dr E Rasmussen for setting up the laboratory and for cooperation and support. We thank C. Müller, F. Hardege and R. Klingberg for their help in field observations and the Finnigan MAT, Bremen, for using their GC-MS systems. This research was financially supported by the Deutsche Forschungsgemeinschaft (nol. Ze 127/4-2).

\section{LITERATURE CITED}

Arn, H., Städtler, E., Rauscher, S. (1975) The electroantennographic detector - a selective and sensitive tool in the gas chromatographic analysis of insect pheromones. Z. Naturforsch. $30 \mathrm{C}: 722-725$

Boilly-Marer, Y (1969). Recherches expérimentale sur la danse nuptial de Platynereis dumerilii Audouin et Milne Edwards (Annelide, Polychaete). Origine et modalité d'action de la substance excitatrice. Cah. Biol. mar. 10: $255-269$

Boilly-Marer, Y (1974). Etude expérimentales du comportement nuptial de Platynereis dumerilii Aud. et M. Edw. (Annelida: Polychaeta): chemorecéption, émission des produits génitaux. Mar. Biol. 24: 167-169

Boilly-Marer, Y., Lassalle, B. (1978). Electrophysiological responses of heteronereids stimulated with sex pheromones (Annelida, Polychaeta). J. exp. Zool. 205: 109-124

Boilly-Marer, Y., Lassalle, B. (1980). Electrophysiological responses of the central nervous system in the presence of homospecific and heterospecific sex pheromones in Nereis (Annelida, Polychaeta). J. exp. Zool. 213: 33-39

Boilly-Marer, Y., L'Homme, M. F. (1986). Sex pheromones in the marine polychaete Platynereis dumerilii Aud. and Edw. In: Porchet, M., Andries, C., Dhainaut, A. (eds.) Advances in invertebrate reproduction 4. Elsevier, Amsterdam, p. 494

Franke, H. D. (1985). On a clocklike mechanism timing lunarrhythmic reproduction in Typosyllis prolifera (Polychaeta). J. comp. Physiol. (Sect. A) 156: 553-561

Goerke, H. (1979). Nereis virens (Polychaeta) in marine pollution research: culture methods and oral administration of a polychlorinated biphenyl. Veröff. Inst. Meeresforsch. Bremerh. 17: 151-161

Grob, K., Zürcher, F. (1976). Stripping of trace organic substances from water. Equipment and procedure. J. Chromatogr. 117: 285-294 
Hardege, J. D., Bartels-Hardege, H., Zeeck, E., Grimm, F. T (1990). Induction of swarming of Nereis succinea. Mar Biol. 104: 291-295

Kaae, R. S., Shorey, H. H., Gaston, L. K. (1973). Pheromone concentration as mechanism for reproductive isolation between two lepidopterous species. Science 179: 487-488

KIun, J. A., Robinson, J. F. (1972). Olfactory discrimination in the european corn borer and several pheromonally analog moths. Ann. Entomol. Soc. Am. 65: 1337-1340

This article was presented by Dr K. Reise, List/Sylt, Germany
Rasmussen, E. (1973). Systematics and ecology of the Isefjord marine fauna (Denmark). Ophelia 11: 1-507

Roelofs, W., Carde, R., Benz, G., von Sális, G. (1971). Sex attractant of the large bud moth found by electroantennogram method. Experientia 27: 1438-1439

Zeeck, E., Hardege, J., Bartels-Hardege, H., Wesselmann, G. (1988). Sex pheromone in a marine polychaete: determination of the chemical structure. J. exp. Zool. 246: 285-292

Manuscript first received: February 10, 1990

Revised version accepted: July 24, 1990 